\title{
Materialism and Individuals' Over-indebtedness: A Case of Indonesia
}

\author{
Janri D. Manafe*, Jappy P. Fanggidae \\ Business Administration Department \\ State Polytechnic of Kupang \\ Kupang, Indonesia \\ *janri.manafe@pnk.ac.id, jappy.fanggidae@pnk.ac.id
}

\begin{abstract}
Over-indebtedness is an ongoing challenge for both employees and institutions. Building on previous works on materialism and over-indebtedness, this study investigated the relationship between the two. We proposed that the effect of materialism trait on over-indebtedness is mediated by selfcontrol over financial issues. Data were collected through a selfadministered survey in public institutions involving 227 employees. The results demonstrated that materialism influenced over-indebtedness both directly or indirectly through self-control over financial issues. The theoretical and practical contributions of the study were discussed.
\end{abstract}

Keywords-materialism, self-control, over-indebtedness, financial management

\section{INTRODUCTION}

Over-indebtedness is a common enemy for individuals, and in a larger scope, for the economy of a country. Unlike indebtedness which is a part of household's regular financial dynamic, over-indebtedness reflects the inability of the household to meet their financial obligations [1]. For the individuals, over-indebtedness can cause serious psychological issues such as stress, depression and even suicidal tendencies [2], not to mention the legal consequences that come with it. Drentea [3] found that when the ratio of debt to income increases, the level of anxiety also increases. In a macro level, high amount of over-indebtedness may affect negatively a country's economy [1].

Over-indebtedness has received ample of attention of scholars for years. For instance, over-indebtedness is associated with individual differences such as materialism, self-esteem, and impulsiveness [4]. Gathergood and Weber [5] also found that over-indebtedness is caused by the failure to control oneself and the lack of financial literacy. Although literature has discussed the impact of individual differences on overindebtedness, most studies only focused on the main predictors of over-indebtedness, and not necessarily discussed the mediating factors that may explicate the mechanism of the relationship [4].

Materialism is one of the antecedents of over-indebtedness. de Matos, et al. [4] argue that materialism is a mediating factor of the impact of self-esteem, impulsiveness, attitude toward debt and credit on consumer indebtedness. In addition, Nepomuceno and Laroche [6] posited that materialism has a positive effect on personal debt and a negative one with account balances. That is, the more materialistic an individual, the more he or she increases debt and the less the money he or she possesses. However, the prior literature did not focus on the mediating factor between materialism and overindebtedness. Considering the importance of materialism value in affecting over-indebtedness, it is surprising that prior research which focuses on highlighting the mediating factor between materialism and over-indebtedness is scarce. This study aims to propose the role of perceived self-control as a mediating factor in such relationship. In a survey, we found that materialism negatively influenced self-control which was in turn negatively affected over-indebtedness. Therefore, we contribute to the literature by presenting the empirical explanation of the link between materialism and overindebtedness.

To provide the contribution, we first review the prior literature on materialism, self-control and over-indebtedness. At the end of the review, we present the hypotheses which would be examined through a set of statistical analyses. Later, we present our contribution to both the literature and to the practitioners. Finally, we discuss our limitation in regard to conducting this research and also propose the direction of future research.

\section{LITERATURE REVIEW}

\section{A. Materialism}

Materialism is defined as "the importance ascribed to the ownership and acquisition of material goods in achieving major life goals" [7]. An individual with high value of materialism focuses on three aspects in their live: success, centrality and happiness [8]. The materialistic individual regards the success of other people and himself/herself by possessions of material goods. Centrality reflects the importance of prosperity in an individual's life. Lastly, the belief that happiness can only be accrued by the possessions of material goods [7]. These three aspects indicate that materialistic people believe that they can 
achieve well-being through the possession of material goods. Unfortunately, the pursue of well-being in this fashion is not effective. Burroughs and Rindfleisch [9] argue that materialistic people are less satisfied with their lives compared with non-materialistic people.

Materialism is a personality trait [10,11]. Belk [11] questioned further whether materialism is a negative of a positive personality trait. In order to answer this question, it is beneficial to see how the relationship between materialism and other personality trait, a preposition to apply impression management practice. For example, Christopher et al. [12] argue that materialistic individuals have tendency to exercise impression management. That is, materialistic individuals like to present himself/herself by exhibiting possession of material goods. Another supporting argument that materialism is a negative trait comes from an experiment conducted by Richins and Dawson [8]. In their experiment, they asked the participants how to spend a windfall of $\$ 20,000$ to measure generosity of the materialists. They found that high materialism individuals were more egoistic than low materialism individuals by spending the money for themselves only and less on charity.

\section{B. The Effect of Materialism on Over-Indebtedness}

Materialistic people relative to less materialistic people have worse financial management skills. Donnelly et al. [13] posited that high materialists compared with low materialists are more likely to mismanage their credit and to purchase goods based on emotional reasons which in turn increase their tendency to conduct compulsive buying. The strong desire to possess materialistic goods motivates high materialists to pay little attention to their financial management issues [14], and neglect risks that may occur (e.g., over-indebtedness). The willingness to take risks is also one of the dispositions of high materialists. For instance, Dittmar, et al. [15] noted that high materialists tend to engage in risky healthy behaviors such as cigarette smoking and alcohol consumptions in order to achieve hedonic purposes.

Materialism has a direct effect on poor financial management of individuals [14]. More specifically, Garðarsdóttir and Dittmar [16] in their two experiments found that materialistic people have more financial anxiety, worse financial management skills and higher amount of debt compared with less materialistic individuals. Garðarsdóttir and Dittmar [16] argue that people who have debt issues perceive themselves as worse money managers than those who do not have debt problems. Since materialistic people have low money management skills, it is sensible to assume that they tend to have over-indebtedness problems compared with less materialistic people.

\section{The Mediating Role of Self-Control}

In a prior study, Gathergood [17] demonstrated that overindebtedness is influenced positively by poor financial literacy and lack of self-control. They found that people with less selfcontrol are more likely to encounter a variety of financial risks such as income shocks and unforeseen expenses. We propose that lack of self-control is caused at least partly by materialism trait. Since materialistic people tend to have poor money management and higher willingness to take financial risks compared with less materialistic individuals, they may have self-control problems over their financial issues. Subsequently, the lack of self-control would lead them to experience overindebtedness [17].

Based on the previous literature, we hypothesize that the relationship between materialism and over-indebtedness is mediated by self-control over financial issues. The following figure 1 illustrates the research model of the study.

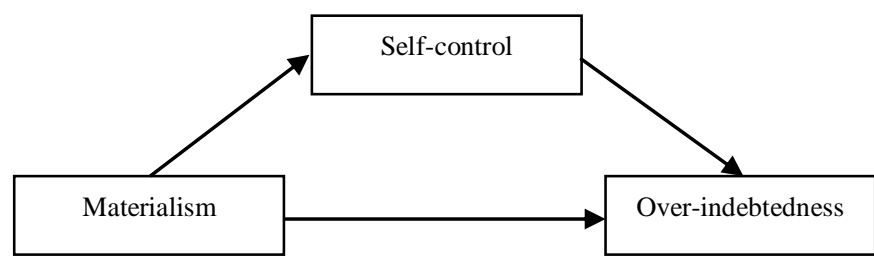

Fig. 1. The mediating role of self-control in the relationship between materialism and over-indebtedness.

\section{METHODS}

\section{A. Sample}

A self-administered survey was performed with 227 adult respondents who currently have regular income as well as capabilities to obtain a long-term credit. A purposive sampling procedure was conducted. The mean age of respondents was 34.50 years old $(\mathrm{SD}=8.02), 124$ women $(55 \%)$ and 103 men $(45 \%)$.

The respondents were employees in three public institutions in Indonesia. The survey was presented through a paper-based survey. In the beginning of the survey, the participants were informed that the survey is anonymous and that they were expected to answer the questions honestly.

\section{B. Measures}

1) Dependent variable: This study used a scale that assess over-indebtedness adopted from Gathergood [17] consisted of 4 items. Sample questions include: "I am/we are keeping all bills and commitments, but it is a constant struggle", and "I am/we are falling behind with some bills or credit commitments."

2) Independent variable: Materialism was measured with a 9 item-scale adapted from Richins [7]. Sample items are, "I admire people who own expensive homes, cars, and clothes," and "I like a lot of luxury in my life."

3) Mediating variable: A 3 item-scale was adapted from Gathergood [17] to measure self-control. Sample items are, "I am prepared to spend now and let the future take care of itself," and "Financial services are complicated and confusing 
to me." All scales were measured on a seven-point scale $(1=$ totally disagree, and $9=$ totally agree).

\section{Descriptive Statistics}

Cronbach alpha of materialism, self-control and overindebtedness indicated a reliable internal consistency within the scales [18]. The results are demonstrated in the following table.

TABLE I. DESCRIPTIVE STATISTICS, CORRELATIONS AND CRONBACH ALPHA

\begin{tabular}{|ll|l|l|l|l|c|}
\hline & Variable & $\boldsymbol{\alpha}$ & \multicolumn{1}{|c|}{ Mean } & \multicolumn{1}{c|}{ SD } & $\mathbf{1}$ & $\mathbf{2}$ \\
\hline 1. & Materialism & .68 & 2.81 & 1.19 & & \\
\hline 2. & Self-control & .78 & 6.50 & .89 & $-.22 * *$ & \\
\hline 3. & $\begin{array}{l}\text { Over- } \\
\text { indebtedness }\end{array}$ & .77 & 5.86 & 1.46 & $.23 * *$ & $-.28 * *$ \\
\hline \multicolumn{6}{|c|}{$* *$ Correlation is significant at the 0.01 level (2-tailed) }
\end{tabular}

\section{RESULTS}

Age and gender were first included as covariates in the analysis. However, since the data pattern with or without the inclusion of age and gender did not show any differences, age and gender were omitted from the main analysis.

The mediation model was analyzed with a bootstrap mediation analysis [Process Model 4; 19] with 5,000 resamples. The results showed that there is a negative and significant effect of materialism on self-control $(b=-.16, \mathrm{SE}=$ $.05, \mathrm{p}<.001)$. This indicates that high materialistic people have less control over themselves in terms of handling their financial issue. The data also confirmed a negative and significant effect of self-control on over-indebtedness $(b=-.38, \mathrm{SE}=.10, \mathrm{p}<$ .001 ), showing that people with low self-control tend to have over-indebtedness in their financial lives. There is also a significant direct effect of materialism on over-indebtedness $(b$ $=.21, \mathrm{SE}=.08, \mathrm{p}<.001)$ More importantly, the indirect effect of materialism on over-indebtedness as mediated by selfcontrol was significant $(\mathrm{b}=.06, \mathrm{SE}=.03,95 \% \mathrm{CI}=.01, .14)$.

\section{DISCUSSION}

This study contributes to literature in two ways. First, it provides mechanism explanation of the relationship between materialism trait and over-indebtedness by proposing the mediating role of self-control. Thus, this study extends prior findings [16,17] which already elaborate the link between materialism and over-indebtedness. Second, while prior studies on materialism and over-indebtedness areas were predominantly conducted in western countries, this study provides another insight from an Asian country (i.e., Indonesia). This is important to the establishment of materialism trait application in various environment.

Practical contributions may be gained by managers and individuals. Although prior study has explained the relationship between materialism and over-indebtedness [16], the mechanism between them was not vivid. Managers may implement a program that may increase self-control of the employees, more specifically to the high materialists, in order to tackle over-indebtedness problems among them. For employees or consumers, it is useful to inspect oneself regarding materialistic values. Subsequently, they may strengthen their self-control and take strategic action to encounter intense persuasive marketing campaign especially on hedonic consumption.

Some limitations in this study can be addressed in future studies. First, this study was conducted in an Asian country (i.e., Indonesia), therefore cultural values may interact with materialism value in influencing self-control and overindebtedness. Future study may conduct cross cultural research and examine the difference between contexts to extend the findings of the current study. Second, while this study relied solely on the survey methods, it is possible that respondents were experiencing interruptions during the data collection. Future studies may follow experimental methods procedure to undermine this issue.

\section{CONCLUSION}

The aim of this study is to investigate the role of selfcontrol as a mediator in the relationship between materialism and over-indebtedness. The results of the analyzed data showed that our predictions are were established. This study also have discussed both the theoretical and practical contributions.

\section{REFERENCES}

[1] S. Angel and K. Heitzmann, "Over-indebtedness in Europe: The relevance of country-level variables for the over-indebtedness of private households," Journal of European Social Policy, vol. 25, no. 3, pp. 331351, 2015.

[2] S. Shen, A.G. Sam, and E. Jones, "Credit card indebtedness and psychological well-being over time: empirical evidence from a household survey," Journal of Consumer Affairs, vol. 48, no. 3, pp. 431456, 2014.

[3] P. Drentea, "Age, debt and anxiety," Journal of health and Social Behavior, pp. 437-450, 2000.

[4] C.A. de Matos, V. Vieira, K. Bonfanti, and F.M.B. Mette, "Antecedents of indebtedness for low-income consumers: the mediating role of materialism," Journal of Consumer Marketing, 2019.

[5] J. Gathergood and J. Weber, "Self-control, financial literacy \& the coholding puzzle," Journal of Economic Behavior \& Organization, vol. 107 , pp. 455-469, 2014

[6] M.V. Nepomuceno and M. Laroche, "The impact of materialism and anti-consumption lifestyles on personal debt and account balances," Journal of Business Research, vol. 68, no. 3, pp. 654-664, 2015.

[7] M.L. Richins, "The material values scale: Measurement properties and development of a short form," Journal of consumer Research, vol. 31, no. 1, pp. 209-219, 2004.

[8] M.L. Richins and S. Dawson, "A consumer values orientation for materialism and its measurement: Scale development and validation," Journal of consumer research, vol. 19, no. 3, pp. 303-316, 1992.

[9] J.E. Burroughs and A. Rindfleisch, "Materialism and well-being: A conflicting values perspective," Journal of Consumer research, vol. 29 , no. 3, pp. 348-370, 2002.

[10] J.M. Otero-López and E. Villardefrancos, "Five-Factor Model personality traits, materialism, and excessive buying: A mediational analysis," Personality and Individual Differences, vol. 54, no. 6, pp. 767 $772,2013$. 
[11] R.W. Belk, "Materialism: Trait aspects of living in the material world," Journal of Consumer research, vol. 12, no. 3, pp. 265-280, 1985.

[12] A.N. Christopher, R.D. Morgan, P. Marek, M. Keller, and K Drummond, "Materialism and self-presentational styles," Personality and Individual Differences, vol. 38, no. 1, pp. 137-149, 2005.

[13] G. Donnelly, M. Ksendzova, and R.T. Howell, "Sadness, identity, and plastic in over-shopping: The interplay of materialism, poor credit management, and emotional buying motives in predicting compulsive buying," Journal of Economic Psychology, vol. 39, pp. 113-125, 2013.

[14] T. Kasser, "Materialistic values and goals," Annual review of psychology, vol. 67, pp. 489-514, 2016.

[15] H. Dittmar, R. Bond, M. Hurst, and T. Kasser, "The relationship between materialism and personal well-being: A meta-analysis," Journal of personality and social psychology, vol. 107, no. 5, p. 879, 2014.
[16] R.B. Garðarsdóttir and H. Dittmar, "The relationship of materialism to debt and financial well-being: The case of Iceland's perceived prosperity," Journal of Economic Psychology, vol. 33, no. 3, pp. 471481, 2012.

[17] J. Gathergood, "Self-control, financial literacy and consumer overindebtedness," Journal of economic psychology, vol. 33, no. 3, pp. 590$602,2012$.

[18] P.R. Hinton, I. McMurray, and C. Brownlow, SPSS explained. Routledge, 2014.

[19] A.F. Hayes, Introduction to mediation, moderation, and conditional process analysis: A regression-based approach. Guilford publications, 2017. 